\title{
Development of an antibody that neutralizes soluble IgE and eliminates IgE expressing B cells
}

\author{
Andrew C. Nyborg ${ }^{1}$, Anna Zacco ${ }^{1}$, Rachel Ettinger ${ }^{1}$, M. Jack Borrok ${ }^{1}$, Jie Zhu ${ }^{1}$, Tom Martin ${ }^{1}$, \\ Rob Woods ${ }^{1}$, Christine Kiefer ${ }^{1}$, Michael A. Bowen ${ }^{1}$, E. Suzanne Cohen ${ }^{2}$, Ronald Herbst ${ }^{1}$, Herren Wu ${ }^{1}$ \\ and Steven Coats ${ }^{1}$
}

Immunoglobulin E (IgE) plays a key role in allergic asthma and is a clinically validated target for monoclonal antibodies. Therapeutic anti-IgE antibodies block the interaction between IgE and the $F c$ epsilon ( $F c \varepsilon$ ) receptor, which eliminates or minimizes the allergic phenotype but does not typically curtail the ongoing production of IgE by $B$ cells. We generated high-affinity anti-IgE antibodies (MEDI4212) that have the potential to both neutralize soluble IgE and eliminate IgE-expressing B-cells through antibody-dependent cell-mediated cytotoxicity. MEDI4212 variants were generated that contain mutations in the $\mathrm{F} c$ region of the antibody or alterations in fucosylation in order to enhance the antibody's affinity for FcyRIIla. All MEDI4212 variants bound to human IgE with affinities comparable to the wild-type (WT) antibody. Each variant was shown to inhibit the interaction between IgE and Fc\&RI, which translated into potent inhibition of FcyRI-mediated function responses. Importantly, all variants bound similarly to IgE at the surface of membrane IgE expressing cells. However, MEDI4212 variants demonstrated enhanced affinity for F $c \gamma$ RIIla including the polymorphic variants at position 158. The improvement in Fc $\gamma \mathrm{RIIla}$ binding led to increased effector function in cell based assays using both engineered cell lines and class switched human IgE B cells. Through its superior suppression of IgE, we anticipate that effector function enhanced MEDI4212 may be able to neutralize high levels of soluble IgE and provide increased long-term benefit by eliminating the IgE expressing B cells before they differentiate and become IgE secreting plasma cells.

Cellular \& Molecular Immunology (2016) 13, 391-400;doi:10.1038/cmi.2015.19;published online 23 March 2015

Keywords: antibody therapeutic; anti-IgE; asthma; IgE; monoclonal antibody

\section{INTRODUCTION}

Immunoglobulin $\mathrm{E}$ (IgE) is the least abundant immunoglobulin isotype present in blood $\left(0.05 \%\right.$ of Ig concentration) ${ }^{1}$ and is capable of activating potent inflammatory reactions. Asthma is a chronic inflammatory disease of the airways characterized by recurring symptoms, airways hyperresponsiveness and variable, reversible airway obstruction and bronchospasm. Asthma is thought to be caused by a combination of genetic and environmental factors. A number of different asthma phenotypes exist, of which allergic asthma, mediated by endogenous allergen-specific IgE antibodies, accounts for at least $50 \%$ of incidence rates. ${ }^{2}$ Most patients with mild-to-moderate disease are treated as symptoms arise with inhaled corticosteroids and long-acting beta 2 agonists combined with short-acting beta2 agonists. Chronic severe asthma occurs in approximately $5 \%$ of the asthmatic population. These patients may continue to experience persistent symptoms, airflow obstruction or frequent exacerbations despite aggressive treatment, including oral corticosteroids. ${ }^{3}$ These conditions negatively affect quality of life and place undue burden on patients and healthcare providers due to adverse effects from regular systemic steroid use. There is a significant unmet medical need for patients with poorly controlled asthma.

The mechanism by which IgE elicits type I hypersensitivity in asthma is well understood. Upon release of IgE from plasma cells, IgE binds via its Fc domain to the high- and low-affinity IgE receptors ( $F_{c \varepsilon R I}$ and $\left.F c \varepsilon R I I\right)$ present on mast cells and basophils. Crosslinking of this receptor-bound IgE by an allergen triggers cell activation and degranulation, resulting in the release of histamine and other mediators of the allergic response.

${ }^{1}$ Medlmmune LLC, Gaithersburg, MD, USA and ${ }^{2}$ Medlmmune Ltd, Milstein Building, Granta Park, Cambridge, UK

Correspondence: Dr A Nyborg, One Medimmune Way, Gaithersburg, MD 20878, USA.

E-mail: nyborga@medimmune.com

Received: 22 December 2014; Revised: 10 February 2015; Accepted: 11 February 2015 
The role of the low-affinity F $\gamma$ receptor, $\mathrm{CD} 23$, is complex, but consequences of $\mathrm{CD} 23$ interaction with IgE include regulation of IgE synthesis, allergen presentation, ${ }^{4}$ allergen transport ${ }^{5,6}$ and cell-mediated effector functions. ${ }^{7}$ The beneficial effects of targeting the IgE pathway for type I hypersensitivity (allergic) responses is well documented ${ }^{8}$ and, in asthma, a clinically validated target. ${ }^{9}$ Omalizumab binds to IgE and blocks the interaction between $\operatorname{IgE}$ and $\mathrm{F} c \gamma \mathrm{R} 1$ and FcERII. This block results in a rapid neutralization of free IgE and gradual downregulation of FcrR1 on basophils, dendritic cells and mast cells. ${ }^{10-12}$ Although IgE is produced and secreted by plasma cells, IgE memory B cells are rare. However, B cell-associated membrane IgE has been described by a number of groups, ${ }^{13-15}$ and antibodies targeting this region are currently in clinical trials. ${ }^{16}$ Membrane IgE-specific monoclonal antibodies are designed to eliminate IgE-expressing $\mathrm{B}$ cells before they become IgE-secreting plasma cells and, overtime, curtail the amount of total free IgE. Because these antibodies target a region that is specific and proximal to the membrane, these antibodies will not bind and neutralize soluble, circulating IgE or inhibit the interaction between IgE and F $c \gamma R I$ and F $c \gamma$ RII. Hence, targeting membrane IgE is unlikely to provide an initial benefit to the patients due to the sustained existence of soluble IgE and long-lived plasma cells that secrete IgE.

The humoral component of the immune system is responsible for antibody-mediated response to pathogens and toxins. This response includes the ability to engage and recruit effector cells. There are multiple antibody classes and isotypes in the human immune system, each with a palette of effector functions, presumably tailored to the nature of the invading pathogen or antigen. Much of our understanding of effector functions mediated by monoclonal antibodies comes from in vitro analyses of antibody-mediated killing. Most antibodydependent cell-mediated cytotoxicity (ADCC) is performed by natural killer (NK) cells that express F $c$ RIIIa as the receptor that interacts with the $\mathrm{F} c$ region of antibodies. Although a variety of techniques have been used to engage effector function and enhance ADCC by monoclonal antibodies, most rely on an improvement in the affinity of the $\mathrm{F} c$ region of the antibody for Fc $\gamma$ RIIIa. ${ }^{17}$ Certain mutations in the $\mathrm{F} c$ region or afucosylation have been shown to enhance the $\mathrm{F} c$ : Fc $c$ RIIIa binding affinity. ${ }^{18,19}$ Whether omalizumab can target membrane-bound IgE B cells and decrease the generation of new IgE-secreting plasma cells in patients is not well understood. We have developed an antibody approach that may have the capacity to both neutralize soluble IgE and eliminate IgEexpressing memory $\mathrm{B}$ cells through an enhanced ADCC mechanism. This approach should have the combined clinical benefits of rapidly neutralizing soluble IgE and eliminating IgE B cells, which, overtime, should reduce the pool of IgEsecreting plasma cells.

\section{MATERIALS AND METHODS}

\section{Recombinant protein and antibody generation}

MEDI4212 wild-type (WT) monoclonal antibody (mAb) was expressed in Chinese Hamster Ovary (CHO) cells and purified as previously described. ${ }^{20,21}$ MEDI4212 aFuc was produced in FUT8-deficient $\mathrm{CHO}$ cells. ${ }^{19}$ Antibodies were purified by Protein A affinity chromatography. MEDI4212 2M2 (S239D/ I332E) and MEDI4212 3M (S239D/A330L/I332E) variants ${ }^{18,22}$ were generated via site-directed mutagenesis using the parental MEDI4212 gene. These constructs were transiently expressed in CHO-CEP6 cells using lipofectimine LTX and CD CHO medium (Life Technologies, Carlsbad, CA, USA).The culture medium was collected 10 days after transfection. MEDI4212 $2 \mathrm{M} 2$ and $3 \mathrm{M}$ were purified by protein A affinity chromatography. Soluble aggregate content was determined by analytical size-exclusion chromatography and removed by preparative size-exclusion chromatography. IgE was purified from U266 cells. ${ }^{23}$ Anti-migis antibody (an antibody specific to the membrane region of $\mathrm{IgE}$ ) was generated internally as described previously. ${ }^{14}$

\section{RBL-2H3 generation and calcium signaling}

ForRI-expressing RBL-2H3 cell were generated as described previously. ${ }^{20}$ In short, human F $\gamma$ RI was cloned from human peripheral blood lymphocytes into pcDNA3.1 vector and transfected, using a standard electroporation method, into RBL-2H3 cells. Transfected cell were cloned by limiting dilution and analyzed for surface Fc $\gamma$ RI expression. The resulting cells were seeded at $5 \times 10^{4} / 100 \mu \mathrm{l} /$ well into 96 -well, black-walled, flatbottomed tissue culture plates (Costar). After $24 \mathrm{~h}$, medium was replaced with test antibodies followed by addition of $\operatorname{IgE}$ to a final concentration of $25 \mathrm{ng} / \mathrm{ml}$. Following a $4 \mathrm{~h}$ incubation at $37{ }^{\circ} \mathrm{C}$, antibody/IgE mixture was aspirated, leaving the cell monolayer intact, and replaced with $100 \mu \mathrm{l} /$ well of FLUO-4AM loading buffer (Dulbecco's modified Eagle's medium with $0.1 \%$ FBS, $20 \mathrm{mM}$ HEPES, $2.5 \mathrm{mM}$ probenecid and $2 \mu \mathrm{g} / \mathrm{ml}$ FLUO4AM (Invitrogen, Life Technologies, Carlsbad, CA, USA)) for $1-2 \mathrm{~h}$ at $37{ }^{\circ} \mathrm{C}$. Cells were washed with phosphate-buffered saline (PBS) and placed in $100 \mu \mathrm{l} /$ well of Fluorometric Imaging Plate Reader (FLIPR) buffer $\left(125 \mathrm{mM} \mathrm{NaCl}_{2}, 5 \mathrm{nM}\right.$ $\mathrm{KCl}, 1 \mathrm{mM} \mathrm{MgCl}_{2}, 1.5 \mathrm{mM} \mathrm{CaCl}_{2}, 30 \mathrm{mM}$ HEPES, $2.5 \mathrm{mM}$ probenecid, $5 \mathrm{mM}$ glucose, $0.01 \% \mathrm{v} / \mathrm{v}$ fetal calf serum) for 5 $45 \mathrm{~min}$ at $37^{\circ} \mathrm{C}$. To measure calcium mobilization following addition of crosslinking anti-IgE, the FLIPR (Molecular Devices, Sunnyvale, CA, USA) was calibrated for suitable exposure according to the manufacturer's instructions. Anti-IgE (BioSource, Life Technologies, Carlsbad, CA, USA), diluted in FLIPR buffer, was added to the assay plates to a final concentration of $2.3 \mu \mathrm{g} / \mathrm{ml}$. Fluorescence of the FLUO-4AM dye was recorded over $2 \mathrm{~min}$ and the peak response exported for analysis using GraphPadPrism software. For mAb crosslinking experiments, RBL-2H3 cells were cultured in the presence of $1 \mu \mathrm{g} / \mathrm{ml} \mathrm{IgE}$ for $4 \mathrm{~h}$ before loading with FLUO4-AM and crosslinking with anti-IgEs as above.

\section{LAD2 $\beta$-hexosaminidase assay}

LAD2 $\beta$-hexosaminidase assays were performed as described previously. ${ }^{20}$ Briefly, LAD2 cells were maintained in serum-free medium (StemPro-34; Life Technologies) supplemented with StemPro-34 nutrient supplement, $2 \mathrm{mM} \mathrm{L}$-glutamine and 
$100 \mathrm{ng} / \mathrm{ml}$ recombinant human stem cell factor (R\&D Systems, Minneapolis, MN, USA). Cells were seeded at a density of $2.5 \times 10^{4}$ cells/well and incubated in a 96-well polypropylene plate with test antibodies for $30 \mathrm{~min}$ at $37{ }^{\circ} \mathrm{C}$ before addition of IgE to a final concentration of $0.15 \mathrm{nM}$. Following a $4-\mathrm{h}$ incubation at $37{ }^{\circ} \mathrm{C}$, cells were washed with buffer to remove excess IgE, and IgE bound to FceRI on the LAD2 cells was crosslinked with anti-IgE $(600 \mu \mathrm{g} / \mathrm{ml}$ goat-261 anti-human IgE; Sigma-Aldrich, St. Louis, MO, USA) for $30 \mathrm{~min}$ at $37^{\circ} \mathrm{C}$. The incubation was stopped by centrifugation at $4{ }^{\circ} \mathrm{C}$, and the cell supernatants analyzed for $\beta$-hexosaminidase content.

\section{Membrane-associated IgE-expressing cell lines}

IgE-expressing cell lines were generated internally and described previously. ${ }^{14}$ Briefly, nucleoporation was used for generating transfected cell lines expressing membrane $\operatorname{IgE}$ (mIgE) on the surface of 293T or NS0 cells. Cells were cotransfected with: (i) a linearized bicistronic mammalian expression vector coding for the $\mathrm{mIgE}$ heavy chain and a $\kappa$-light chain; the variable domains of the mIgE were derived from an antibody that binds the F-protein of respiratory syncytial virus; and (ii) a linearized bicistronic mammalian expression vector coding for CD79a and CD79b. CD79a and CD79b associate with membrane immunoglobulins to form the B-cell receptor complex. ${ }^{24}$ Twenty-four hours after cotransfection, cells were seeded at 500 cells/well in 96-well plates and subjected to double selection with $500 \mu \mathrm{g} / \mathrm{ml}$ neomycin (for the IgE-expressing plasmid) and $100 \mu \mathrm{g} / \mathrm{ml}$ hygromycin (for the CD79a- and CD79bexpressing plasmid) in Dulbecco's modified Eagle's medium (Invitrogen). After 2-3 weeks, colonies surviving double selection were expanded and tested for expression of mIgE, CD79a and CD79b. Colonies with expression of all three were sorted by three-color fluorescence-activated cell sorting (FACS) into a single cell per well. Those clones with constant expression of mIgE, CD79a and CD79b were subcloned by limited dilution cloning at 0.2 cells/well to ensure monoclonality.

\section{FACS labeling}

Cell surface labeling and FACS analysis were performed as described previously. ${ }^{25}$ Briefly, 293TIgE-expressing cells were grown in Dulbecco's modified Eagle's medium with high glucose, $L$-glutamine, sodium pyruvate, $10 \%$ FBS, $1 \%$ geneticin and $0.8 \%$ hygromycin. Medium was removed and the cells were washed with PBS. TrypLE Express was added to remove cells from the plates. Serum-containing medium was added to neutralize trypsin, and cells were washed with $10 \mathrm{ml}$ PBS and resuspended at $2 \times 10^{7}$ cells $/ \mathrm{ml}$ in FACS block (PBS with $3 \%$ bovine serum albumin and $0.1 \%$ sodium azide, $\mathrm{pH} 7.2$ ). Cells were incubated in FACS block for $30 \mathrm{~min}$ on ice. All primary antibodies were used at $10 \mu \mathrm{g} / \mathrm{ml}$ and incubated on ice for $1 \mathrm{~h}$. Cells were washed three times by centrifugation at 2000 r.p.m. for $3 \mathrm{~min}$ and the cell pellet was resuspended in $200 \mu \mathrm{l}$ of FACS buffer. A $100 \mu \mathrm{l}$ volume of Alexa Fluor 647AffiniPure goat anti-human IgG Fo fragment-specific antibody diluted at $1: 400$ into FACS block was added to the cells, and the cells were incubated on ice for $1 \mathrm{~h}$. The primary IgG control was incubated in IgG1 control antibody and the secondary control received secondary antibody only.

\section{FchRIIIa enzyme-linked immunosorbent assay (ELISA) and Biacore assays}

An ELISA was used to characterize the binding of MEDI4212 variants to human FC RIIIa (158V or 158F). Individual wells of a 96-well Maxisorp Immunoplate (Nunc, Thermo Scientific, Waltham, MA, USA) were coated overnight at $4{ }^{\circ} \mathrm{C}$ with a $10 \mu \mathrm{g} / \mathrm{ml}$ solution of $\mathrm{mAb}$ and blocked with Pierce protein-free T20 block (Thermo Scientific, Waltham, MA, USA) for $1 \mathrm{~h}$ at $22{ }^{\circ} \mathrm{C}$. Plates were washed three times with PBST (PBS with $0.1 \%$ Triton $\mathrm{X}-100)$. Incubation with four-fold serially diluted samples of Flag-tagged hFc $\gamma$ RIIIa (158V or 158F) at concentrations typically starting from $100 \mu \mathrm{g} / \mathrm{ml}$ for $1 \mathrm{~h}$ at $22{ }^{\circ} \mathrm{C}$. Plates were incubated with anti-FLAG BioM2 antibody (SigmaAldrich, St. Louis, MO, USA) at 1:100 dilution followed by streptavidin horseradish peroxidase conjugate (Invitrogen) at $0.1 \mu \mathrm{g} / \mathrm{ml}$ for $30 \mathrm{~min}$ at $22^{\circ} \mathrm{C}$. Plates were developed by adding $50 \mu \mathrm{KPL}$ SureBlue TMB for $10 \mathrm{~min}$ in the dark and stopped with the addition of KPL TMB Stop Solution ( $50 \mu \mathrm{l}$ per well). All plates were read by measuring the OD at $450 \mathrm{~nm}$ on a Spectra MAX plate reader.

Surface plasmon resonance was used to measure kinetic rates and binding constants as described previously. ${ }^{26}$ The equilibrium dissociation constant $\left(\mathrm{K}_{\mathrm{D}}\right)$ for the binding of MEDI4212 IgG Fcvariants to hFc RIIIA-158V and hFc RIIIA-158F was measured on a Biacore 3000 instrument (Biacore, Piscataway, NJ, USA).The MEDI4212 IgGs were immobilized at high density on a CM5 sensor chip using a standard amino coupling chemistry as outlined by the instrument manufacturer. The final surface density of MEDI4212 measured approximately 2000 resonance units. A reference flow cell was also prepared on this sensor chip using the identical immobilization protocol minus IgG. The stock solution and final concentration series of hFc $\gamma$ RIIIA-158V and hFc $\gamma$ RIIIA-158F were prepared in instrument buffer as 0.978-16 $000 \mathrm{nM}$ and 1.95-32 000, respectively. The instrument buffer was composed of PBS/Tween/ethylenediaminetetraacetic acid buffer containing $50 \mathrm{mM}$ phosphate, $\mathrm{pH}$ 7.4, $150 \mathrm{mM} \mathrm{NaCl}, 3 \mathrm{mM}$ ethylenediaminetetraacetic acid and $0.005 \%$ Tween-20. Receptor solutions were injected over IgG surfaces for $50 \mathrm{~min}$ at a flow rate of $5 \mu \mathrm{l} / \mathrm{min}$, and the binding data were collected. Following each injection, bound receptor was removed with a brief pulse (injection) of $5 \mathrm{mM}$ $\mathrm{HCl}$. Once binding data had been collected for the entire concentration series, the steady-state data were fit to a one-site ( $1: 1)$ binding model to determine the $K_{D}$ for each interaction.

\section{Primary peripheral blood mononuclear cell (PBMC) IgE class switch, IgE quantitation and IgE ELISpot}

IgE class switching in PBMCs was described previously. ${ }^{14}$ Human whole blood was collected from healthy donors in accordance with IRB approval and corporate bioethics policies in sodium citrate cell preparation tubes and centrifuged at $1700 \mathrm{~g}$ for $25 \mathrm{~min}$ at room temperature. The red blood cells were predominantly beneath the density gradient, and the 
supernatant, containing PBMCs, was decanted. PBMCs were centrifuged at $524 \mathrm{~g}$ for $7 \mathrm{~min}$ and the supernatant was aspirated. Pellets were resuspended in $10 \mathrm{ml}$ of complete medium (RPMI minus phenol red, $2 \%$ penicillin-streptomycin, $1 \% \mathrm{~L}$-glutamine, $0.1 \% \beta$-mercaptoethanol, $10 \%$ FBS and $0.5 \%$ HEPES). Cells were centrifuged for $10 \mathrm{~min}$ at $200 \mathrm{~g}$ with the brake off. Supernatants were aspirated and residual red blood cells were lysed in ACK lysis buffer according to the manufacturer's instructions. Lysis was quenched in less than $5 \mathrm{~min}$ with the addition of $10 \mathrm{ml}$ of complete medium. Cells were centrifuged for $5 \mathrm{~min}$ at $524 \mathrm{~g}$. Cell pellets were resuspended in $10 \mathrm{ml}$ of complete medium and passed through a $50 \mu \mathrm{m}$ filter. Freshly isolated PBMCs $\left(1 \times 10^{6}\right.$ cells/well) were IgE class-switched by incubation with interleukin-4 (IL-4) $(10 \mathrm{ng} / \mathrm{ml})$ and anti-CD40 $(1 \mu \mathrm{g} / \mathrm{ml})$ and co-incubated with $10 \mu \mathrm{g} / \mathrm{ml}$ of either IgG1 isotype control, MEDI4212 aFuc or anti-migis F4 aFuc (positive control) at $37{ }^{\circ} \mathrm{C}$ for 7 days in a $5 \% \mathrm{CO}_{2}$ incubator. Following the 7 day incubation, cells were washed two times in complete medium and transferred to Mabtech IgE ELISpot plates and incubated for $24 \mathrm{~h}$ at $37{ }^{\circ} \mathrm{C}$ in a $5 \% \mathrm{CO}_{2}$ incubator. The Mabtech IgE ELISpot protocol was followed for IgE ELISpot development. ELISpot images and spot quantitation were performed using a Bioreader 5000-F $\alpha$ from BIO-SYS GmbH, Karben, Germany.

RNA was isolated from class-switched PBMCs with the RNeasy Plus Micro kit (Qiagen, Venlo, Netherlands), treated with DNaseI and reverse transcribed with oligo $(\mathrm{dT})_{20}$ primers using the SuperScript III first-strand synthesis kit as suggested by the manufacturer (Invitrogen). Ten percent of the cDNA reaction was analyzed using TaqMan Fast Universal PCR Master Mix (2X) andNo AmpErase UNG TaqMan chemistry (Catalog \#4352042; Life Technologies), and quantitative RTPCR was performed in a Prism 7900HT (Applied Biosystems, Foster City, CA, USA). IgE expression was calculated after amplification with a custom-designed IgE-specific TaqMan assay (forward primer: CCGTGTGGCACACACTC; Reverse primer: GTCGCAGGACGACTGTAAG; TaqMan probe: FAM-TCGTCCACAGACTGGGTGGACAAC-TAMRA) and comparison to an 18S internal control (Catalog \# Hs99999901-s1; Life Technologies) using the comparative $C_{\mathrm{t}}$ method. ${ }^{27}$ The foldchange in IgE expression among class-switch samples incubated with antibody versus control class-switched samples was determined.

\section{Antibody-dependent cellular cytotoxicity assay}

The ADCC activity of the antibodies was assessed as follows. Transfected IgE target cells, 293T cells and 293T expressing membrane IgE or NS0 and NS0 cells expressing membrane IgE, CD79a and CD79b were harvested using cell dissociation buffer (Invitrogen) and resuspended in ADCC assay buffer (RPMI 1640 supplemented with 5\% FBS) at a density of $2 \times 10^{5} \mathrm{cells} / \mathrm{ml}$. The cells were added to a 96-well round bottom tissue culture plate (BD Biosciences, Franklin Lakes, New Jersey, USA) at $50 \mu \mathrm{l} /$ well, along with various concentrations of antibody at $50 \mu \mathrm{l} /$ well in ADCC assay buffer, and pre-incubated at $37^{\circ} \mathrm{C}$ for $30 \mathrm{~min}$. As a positive control, ADCC activity of anti-CemX.migis antibodies with mIgE-expressing 293T and NS0 cells as targets was tested at different doses. A transformed NK cell line was used as effector cell at an E/T ratio of $2.5: 1{ }^{14}$ Cells were incubated with serial dilutions of antibody for $5 \mathrm{~h}$. Target cell lysis was measured by detecting the release of lactate dehydrogenase (LDH). All assays were performed in triplicate. For maximum cell lysis, $25 \mu \mathrm{l} /$ well of $9 \%$ Triton X100 (BD Biosciences, Franklin Lakes, New Jersey, USA) was added to the control wells. The plates were centrifuged at $300 \mathrm{~g}$ for $3 \mathrm{~min}$ and incubated at $37^{\circ} \mathrm{C}$ for $4 \mathrm{~h}$. Plates were then centrifuged at $300 \mathrm{~g}$ for $10 \mathrm{~min}$, and $50 \mu \mathrm{l}$ of supernatant from each well containing LDH released from lysed cells was transferred to MaxiSorp 96-well plates (BD Biosciences). A $50 \mu \mathrm{l}$ volume of reconstituted substrate mix (CytoTox 96 NonRadioactive Cytotoxicity Assay kit; Promega) was added to the wells, and plates were incubated in the dark at room temperature for $30 \mathrm{~min}$. Reactions were terminated with $50 \mu \mathrm{l} \mathrm{stop}$ solution (Promega). LDH activity was quantified by measuring the absorbance at $490 \mathrm{~nm}$. Percent cytotoxicity was calculated as follows:

\section{Percent cytotoxicity $=$}

(experimental-effectorspontaneous-target spontaneous)/

(target maximum - target spontaneous) $\times 100$

where experimental corresponds to the signal measured in experimental wells; effector spontaneous corresponds to the signal measured in the presence of PBMCs alone; target spontaneous corresponds to the signal measured in the presence of 293T (transfected or untransfected) target cells alone; and target maximum corresponds to the signal measured in the presence of detergent-lysed 293T cells (transfected or untransfected).

\section{NK/F $c \gamma$ RIIIa-NFAT cells and assay description}

Classic ADCC is triggered when the Fc domain of a mAb associates with FcyRIIIa receptors on the surface of effector cells. This antibody-F $c$ RIIIa binding event triggers signaling events that induce the release of granzyme $B$ and perforin, causing perforation of the target cell membrane and entry of granzyme B, which results in cell killing. A surrogate reporter bioassay for ADCC effector function was generated by transducing (lentiviral vectors) Fc RIIIa (158V) in NK-92 cells. Infected populations were sorted for high levels of cell surface FcyRIIIa expression. Surrogate monitoring of ADCC was achieved by co-expression of NFAT-luciferase reporter genes. Activation of FcyRIIIa induces NFAT signaling. ${ }^{28}$ A ratio of $2: 1$ (T/E) was found to achieve the most consist results with the NK/ FcrRIIIa-NFAT reporter cells.

\section{RESULTS}

\section{MEDI4212 variants have increased affinity for Fc $\gamma$ RIIIa}

We previously reported a high-affinity neutralizing anti-IgE, MEDI4212. ${ }^{20}$ Fc region variants of this antibody were generated to enhance ADCC effector function. Four separate constructs were generated: (i) MEDI4212WT; (ii) MEDI4212 2M2, which 
contains mutations S239D and I332E in the Fc region that have been show to enhance ADCC; ${ }^{18}$ (iii) MEDI4212 3M,which contains mutations S239D, A330L and I332E in the $\mathrm{F} c$ region that have been shown to enhance ADCC; ${ }^{18}$ and (iv) MEDI4212 aFuc, which is WTMEDI4212 produced in FUT8-deficient $\mathrm{CHO}$ cells and elicits an afucosylated IgG1thathas been shown to increase ADCC activity. ${ }^{19}$ Activation and engagement of effector function results from effector cell receptors interacting with the $\mathrm{F} c$ region of antibodies bound to pathogens or antigens. The interaction between the $\mathrm{F} c$ region of an antibody and the receptor FcrRIIIa is key to ADCC and is driven by the affinity between the $\mathrm{F} c$ region and its receptor, $\mathrm{F} c \mathrm{R}$ RIII. In vitro assays were established to evaluate the affinity of the $\mathrm{F} c$ region of the MEDI4212 variants to Fc $\gamma$ RIIIa. Two commonly occurring genetic polymorphisms of the Fcy RIIIa receptors (158V and $158 \mathrm{~F}$ ) have been described and are known to influence binding to IgG1. ${ }^{29} 158 \mathrm{~V}$ mediates high-affinity binding and $158 \mathrm{~F}$ mediates lower-affinity binding to $\mathrm{Fc}$ receptors. Binding of MEDI4212 to FcyRIIIa was evaluated by ELISA (Figure 1 for $158 \mathrm{~V}$ or $158 \mathrm{~F}$, respectively). As anticipated, the binding of MEDI4212 WT was considerably lower (approximately 100fold) for $158 \mathrm{~F}$ than for 158V (Table 1). All MEDI4212 variants showed significant improvement in F $c \gamma$ RIIIa binding (Figure 1), and this improvement was particularly dramatic for $158 \mathrm{~F}$ (Figure 1b). Surface plasmon resonance was used to determine the $K_{\mathrm{D}}$ for MEDI4212 variants and ForRIIIa. The relative improvement in affinity was similar to the improvements observed by ELISA (Table 1).

\section{MEDI4212 variants bind cell surface IgE}

293Tand NS0 cells were engineered to express IgE-containing the membrane region. To verify that the cells expressed IgE at the surface and that it could be bound by MEDI4212, flow cytometry was performed. MEDI4212 did not bind to the surface of control 293T (Figure 2b). However, MEDI4212 and variants all showed significant binding to the membrane IgEtransfected 293T cells (Figure 2a) and NS0 cells. No binding was observed with an IgG1 control (Figure 2a, red line) or antihuman Alexa 647 secondary control (Figure 2a, gray line). These data suggest that the vast majority of IgE-engineered cells express IgE at the surface, and that the antibodies bind to the surface IgE.

\section{MEDI4212 variants inhibit IgE-Fc\&R1 interaction}

The primary mechanism of action by which anti-IgE (omalizumab) inhibits the IgE-mediated phenotype is by inhibition of IgE interacting with $\mathrm{F} \gamma \gamma \mathrm{R} 1$ on the surface of basophils and mast cells. MEDI4212 variants were evaluated for their ability to prevent IgE-FceR1 interaction. RBL-2H3 (rat basophilic cell line) cells were stably transfected with human FceR1. Activation of FceR1 receptor by crosslinking receptor-bound IgE leads to calcium mobilization that was detected using an FLIPR. All MEDI4212 variants were potent inhibitors of IgE-induced signaling (Figure 2c). Changes in the MEDI4212 Fc region had no effect on the antibody's ability to potently inhibit IgE-Fc R1 interaction (Calcium Flux). Additionally, human mast cells (LAD2 cells) that naturally express human FceR1 were used to evaluate activation of FceR1 signaling. Addition of IgE to these cells leads to crosslinking the receptor bound IgE, activation of cells and secretion of mediators such as histamine and beta-hexosaminidase. All MEDI4212 variants were potent inhibitors of IgE-induced beta-hexosaminidase release (Figure 2d).

\section{MEDI4212 variants have enhanced ADCC activity}

An increase in antibody affinity for F $\gamma$ RIIIa has been shown to enhance effector function and ADCC activity. ${ }^{18,30-32}$ A variety of assays were performed to demonstrate that MEDI4212 variants enhance ADCC. 293Tor NS0 cells that overexpress surface IgE (membrane-bound) were used as target cells for these assays. First, a surrogate reporter assay for ADCC was established using NK/FcyRIIIa-NFAT cells that overexpress FcyRIIIa (158V) and NFAT-luciferase and provide a relative measure for activation of the Fc $\gamma$ RIIIa signaling pathway. Consistent with its weak binding to FcyRIIa (Figure 1), MEDI4212 WT had minimal activity in this assay (Figure 3a). MEDI4212 aFuc, $3 \mathrm{M}$ and $2 \mathrm{M} 2$ had average $\mathrm{EC}_{50}$ values of $28.6 \pm 11.2 \mathrm{ng} / \mathrm{ml}, 28.9 \pm 9.2 \mathrm{ng} / \mathrm{ml}$ and $38.9 \pm 13.5 \mathrm{ng} / \mathrm{ml}$, respectively, $n=5$ (Figure $3 \mathrm{a}$ ).Second, as a more direct measure of cell killing,KC133 natural killer cells were added to 293T-IgE
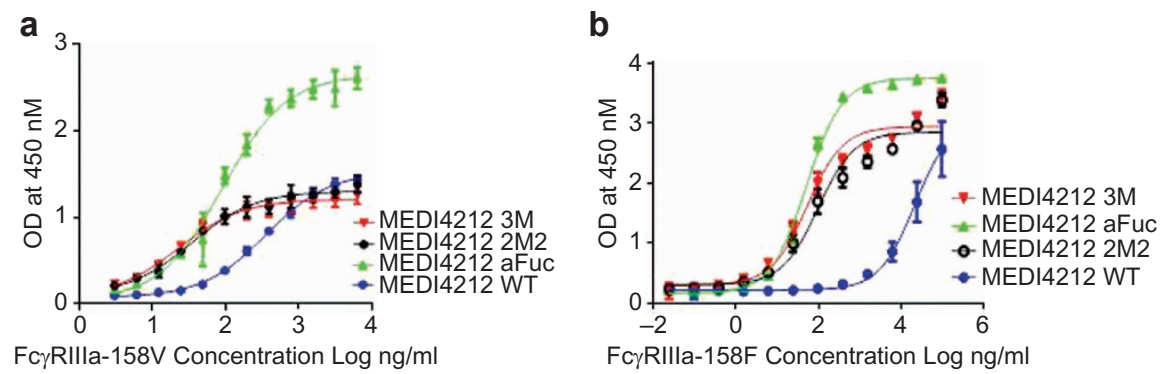

Figure 1 MEDI4212 variants have increased affinity for FC $\gamma$ RIIIa (ELISA). MEDI4212 variants were coated on plates and assessed for binding to: (a) Fc rRIIla-FLAG (158V) MEDI4212 afuc, 3M 2M2 and WT had EC50 values of $64.1 \pm 23.6 \mathrm{ng} / \mathrm{ml}, 19.0 \pm 7.3 \mathrm{ng} / \mathrm{ml}, 20.5 \pm 11.8 \mathrm{ng} / \mathrm{ml}$ and $272.7 \pm 78.3 \mathrm{ng} / \mathrm{ml}$, respectively ( $n=3$ ); (b) FcyRIIla-FLAG (158F) MEDI4212 afuc, 3M 2M2, and WT had EC 50 values of $72.0 \pm 25.8 \mathrm{ng} / \mathrm{ml}$, $56.0 \pm 6.4 \mathrm{ng} / \mathrm{ml}, 112.0 \pm 31.2 \mathrm{ng} / \mathrm{ml}$ and $27696 \pm 4977 \mathrm{ng} / \mathrm{ml}$, respectively $(n=3)$. MEDI4212 variants demonstrated enhanced binding to both Fc $\gamma$ RIIla types compared with MEDI4212 WT. 
Table $1158 \mathrm{~V}$ and $158 \mathrm{~F}$ affinity measurements

\begin{tabular}{|c|c|c|c|c|}
\hline & MEDI4212 3M & MEDI4212 2M2 & MEDI4212 aFuc & MEDI4212 WT \\
\hline 158V ELISA & 19.0 & 20.5 & 64.1 & 272.7 \\
\hline Average of three studies & (7.3) & (11.8) & $(23.6)$ & (78.3) \\
\hline \multicolumn{5}{|l|}{$\mathrm{EC}_{50} \mathrm{ng} / \mathrm{ml}$ (s.d.) } \\
\hline \multicolumn{5}{|l|}{ Average of three studies } \\
\hline \multicolumn{5}{|l|}{$\mathrm{K}_{\mathrm{D}} \mathrm{nM}$} \\
\hline \multicolumn{5}{|l|}{$\mathrm{EC}_{50} \mathrm{ng} / \mathrm{ml}$ (s.d.) } \\
\hline 158F Biacore & 36 & 67 & 389 & 4963 \\
\hline \multicolumn{5}{|l|}{ Average of three studies } \\
\hline $\mathrm{K}_{\mathrm{D}} \mathrm{nM}$ & & & & \\
\hline
\end{tabular}

Abbreviation: WT, wild-type.

target cells at a $2.5: 1(\mathrm{E} / \mathrm{T})$ ratio. Cytotoxicity was assessed by quantitatively measuring the release of lactate dehydrogenase. MEDI4212 variants had enhanced ADCC-mediated killing when compared to MEDI4212 WT. MEDI4212aFuc, 3M and $2 \mathrm{M} 2 \mathrm{had}$ average $\mathrm{EC}_{50}$ values of $18.9 \pm 11.5 \mathrm{ng} / \mathrm{ml}, 13.3 \pm 9.7 \mathrm{ng} /$ $\mathrm{ml}$ and $21.7 \pm 6.0$, respectively, $n=6$ (Figure $3 \mathrm{~b}$ ). Although nearly $100 \%$ of the cells appeared to be labeled by MEDI4212 in the flow cytometry analyses (IgE expression at the cell surface), only $20 \%-30 \%$ cytoxicity was observed in the ADCC assay. Longer incubation times and a higher $\mathrm{E} / \mathrm{T}$ ratio did not improve the percent cytotoxicity observed. Similar studies were performed using IgE-NSO target cells (Figure 3c).

\section{a}
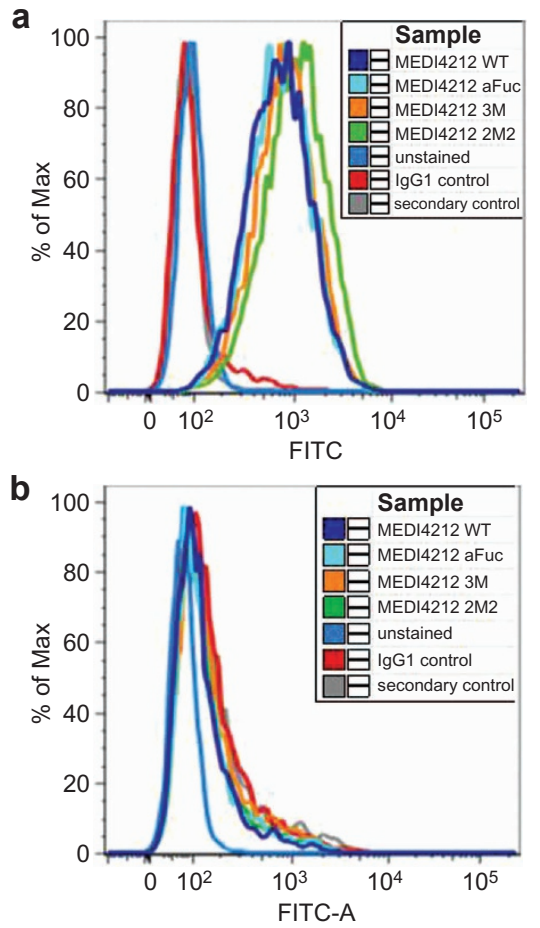

C

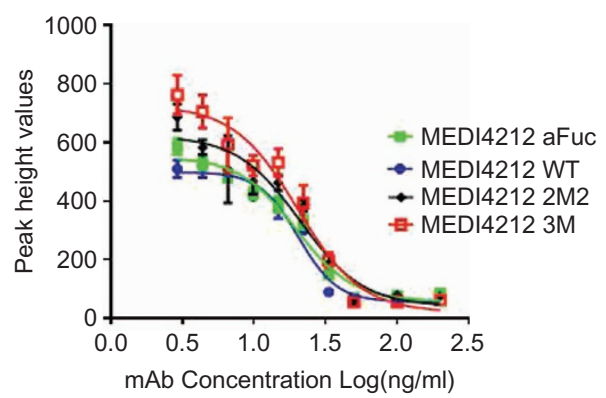

d

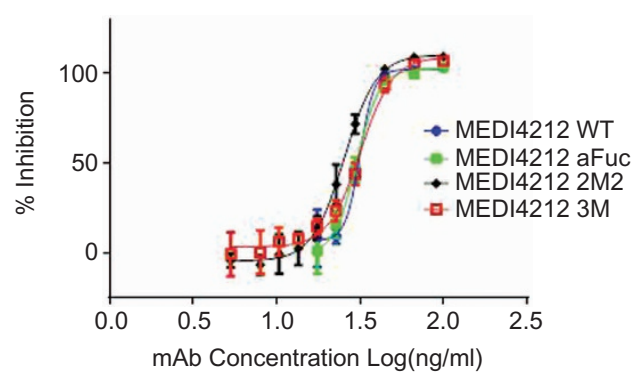

Figure 2 MEDI4212 variants inhibit Calcium Flux and degranulation, and bind cell surface-associated IgE. 293T and NSO cells were engineered to express IgE at the surface. (a) MEDI4212 was used to detect the IgE-expressing cells by flow cytometry. MEDI4212 variants bind to the surface of IgE-expressing cells as efficiently as MEDI4212 WT. (b) MEDI4212 variants do not bind to the surface of WT293T cells. (c) RBL-2H3 (rat basophilic

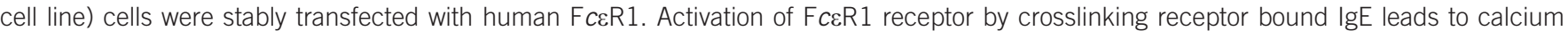
mobilization that can be detected using FLIPR ( $n=3$, representative shown). (d) Human mast cells (LAD2 cells) naturally express human FceR1 ( $n=3$, representative shown). Activation of F $c \varepsilon R 1$ receptor by crosslinking receptor-bound IgE leads to activation of cells and secretion of mediators such as beta-hexosaminidase. MEDI4212 WT and ADCC-enhanced variants all inhibit calcium mobilization (c) and beta-hexosaminidase release (d) in a dose-dependent manner. ADCC, antibody-dependent cell-mediated cytotoxicity; FLIPR, Fluorometric Imaging Plate Reader; IgE, immunoglobulin E; WT, wild-type. 

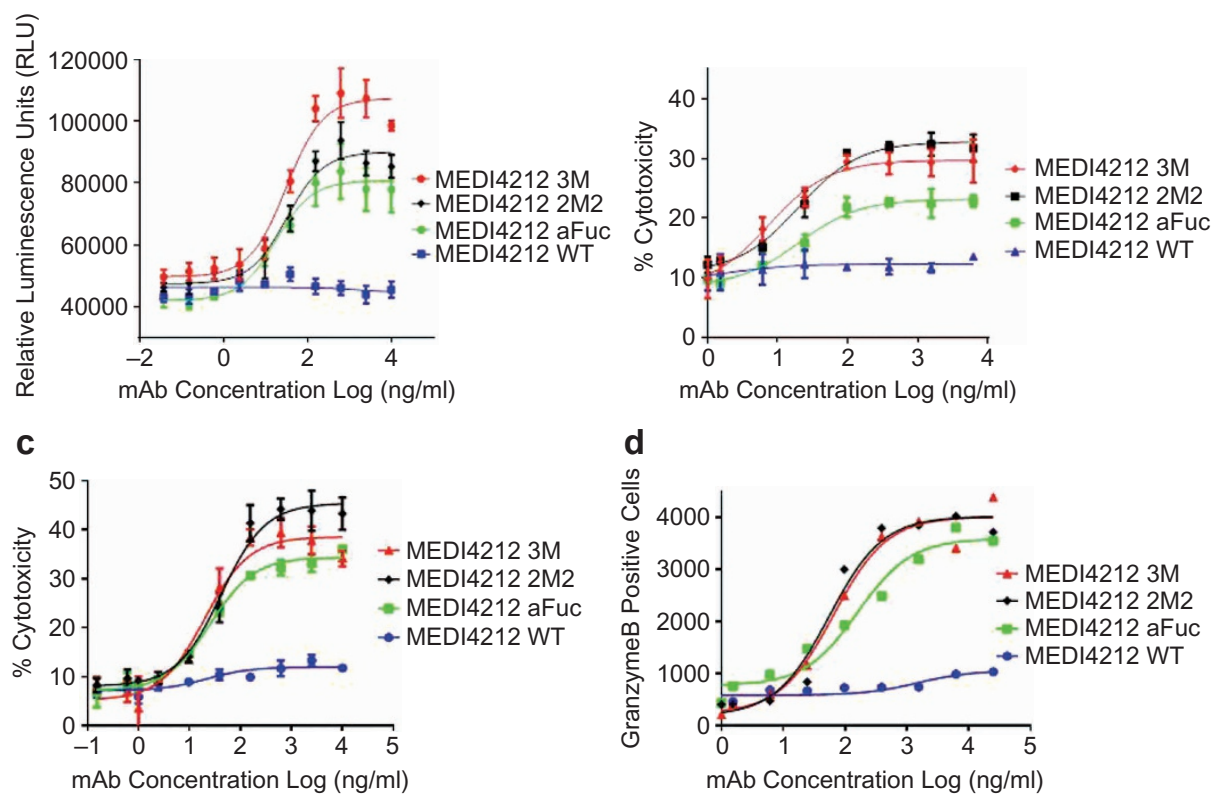

Figure 3 MEDI4212 variants enhance ADCC killing of IgE-expressing cells. MEDI4212 WT and variants were evaluated for ADCC activity in four

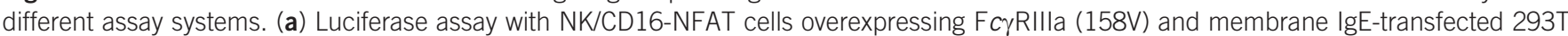
target cells. MEDI4212 aFuc, $3 \mathrm{M}$ and $2 \mathrm{M} 2$ had average $\mathrm{EC}_{50}$ values of $28.6 \pm 11.2 \mathrm{ng} / \mathrm{ml}, 28.9 \pm 9.2 \mathrm{ng} / \mathrm{ml}$ and $38.9 \pm 13.5 \mathrm{ng} / \mathrm{ml}$, respectively $(n=5)$. (b) KC133 natural killer cells and 293T-lgE target cells at a 2.5: 1 (E/T) ratio. LDH release was quantified as a measure of cell cytotoxicity after $14 \mathrm{~h}$. MEDI4212 aFuc, 3M and $2 \mathrm{M} 2$ had average an $\mathrm{EC}_{50}$ of $18.9 \pm 11.5 \mathrm{ng} / \mathrm{ml}, 13.3 \pm 9.7 \mathrm{ng} / \mathrm{ml}$, and $21.7 \pm 6.0$, respectively $(n=6)$. (c) KC133 and NSO-lgE target cells at a 2.5: 1 (E/T) ratio. LDH release was quantified as a measure of cell cytotoxicity after $14 \mathrm{~h}$. MEDI4212 aFuc, $3 \mathrm{M}$ and $2 \mathrm{M} 2 \mathrm{had}$ an $\mathrm{EC}_{50}$ of $25.6 \pm 7.2 \mathrm{ng} / \mathrm{ml}, 20.0 \pm 9.0 \mathrm{ng} / \mathrm{ml}$ and $41.7 \pm 12.6 \mathrm{ng} / \mathrm{ml}$, respectively $(n=6)$. (d) $\mathrm{KC} 133$ and NSO-lgE target cells at a $5: 1$ $(E / T)$ ratio. Granzyme B signaling was detected by flow cytometry after $15 \mathrm{~min}$. MEDI4212 aFuc, $3 \mathrm{M}$ and $2 \mathrm{M} 2 \mathrm{had}$ an average $\mathrm{EC}_{50}$ of $160 \pm 30.2 \mathrm{ng} /$ $\mathrm{ml}, 64.8 .0 \pm 23.0 \mathrm{ng} / \mathrm{ml}$ and $55.4 \pm 21.6 \mathrm{ng} / \mathrm{ml}(n=3)$. MEDI4212 ADCC variants, but not MEDI4212 WT, mediated effective target cell killing in all assay formats tested. ADCC, antibody-dependent cell-mediated cytotoxicity; IgE, immunoglobulin E; LDH, lactate dehydrogenase; NK, natural killer; WT, wild-type.

MEDI4212 variants consistently demonstrated enhanced cell killing. MEDI4212 aFuc, $3 \mathrm{M}$ and $2 \mathrm{M} 2$ had $\mathrm{EC}_{50}$ values of $25.6 \pm 7.2 \mathrm{ng} / \mathrm{ml}, 20.0 \pm 9.0 \mathrm{ng} / \mathrm{ml}$ and $41.7 \pm 12.6 \mathrm{ng} / \mathrm{ml}$, respectively $(n=6)$. A maximum cytotoxic effect of $30-50 \%$ was observed using IgE NS0 cells as the target cells. Finally, granzyme B and downstream caspase activity are fundamental early biochemical signatures of cytoxicity. PanToxiLux is a commercially available kit that measures intracellular granzyme B and caspase signaling via cleavage of a cell-permeable fluorogenic substrate that is measured by flow cytometry. It is a cell-based kit designed to measure the cytotoxicity by lymphocytes to individual target cells. NS0-IgE target cells were used for these studies. KC133 natural killer cells were added at a 5:1 (E/T) ratio, and cells were incubated for 15-30 min. Fluorogenic signaling was detected by flow cytometry. MEDI4212 variants consistently enhanced cell killing. MEDI4212 aFuc, 3M and $2 \mathrm{M} 2 \mathrm{had}$ an average $\mathrm{EC}_{50}$ of $160 \pm 30.2 \mathrm{ng} / \mathrm{ml}, 64.8 .0 \pm 23.0 \mathrm{ng} /$ $\mathrm{ml}$ and $55.4 \pm 21.6 \mathrm{ng} / \mathrm{ml}$, respectively $(n=3)$ (Figure $3 \mathrm{~d}$ ).

\section{MEDI4212 aFuc and 3M eliminate IgE class-switched human PBMCs}

We sought to establish a human ex vivo assay using classswitched IgE cells. A variety of class switching conditions were tested. The most common conditions used include the addition of IL-4 and anti-CD40 or CD40L. ${ }^{33}$ Other studies have also included IL-17A $\mathrm{A}^{34}$ or IL-21. ${ }^{35,36}$ We tested a variety of combinations and ratios of these conditions and found that IL-4plus anti-CD40 gave the most consistent IgE class switching results. In purified human B-cell preparations, only a small number of the total B-cells were found to class switch to $\operatorname{IgE}$ as analyzed by FACS, ELISA, qPCR and ELISpot. The B cells from some donors consistently class-switched better than others. In order to understand the PBMCs from our donor population, we genotyped for Fc $\gamma$ RIIIa variants, $158 \mathrm{~V}$ and $158 \mathrm{~F}$. Interestingly, as observed by others, we found mostly heterozygous $158 \mathrm{~V} / \mathrm{F}(48 \mathrm{~V} / \mathrm{F}, 3 \mathrm{~V} / \mathrm{V}$ and $0 \mathrm{~F} / \mathrm{F})$ in our limited donor population. ${ }^{37-39}$ Once conditions for IgE class switching had been optimized in purified B-cell preparations, PBMCs were harvested from the same donors and class-switched using identical conditions. IgEElispot, IgE ELISA and IgE qPCR were used to verify IgE class switching and expression. The addition of MEDI4212 aFuc, 3M or the anti-migis antibody, an antibody specific to the membrane region of $\mathrm{IgE},{ }^{14}$ consistently reduced the number of IgE-expressing cellsto background levels noted in unstimulated cells (Figure 4a). Additionally, MEDI4212aFuc, 3M or anti-migis antibody elicited a substantial drop in the level of IgE expression as observed by qPCR (Figure 4b). 

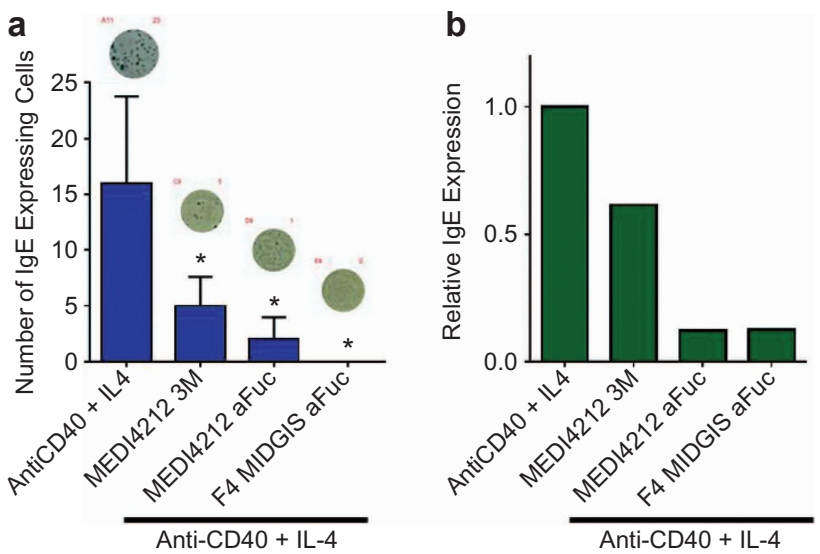

Figure 4 MEDI4212 aFuc enhance killing of primary IgE classswitched human PBMCs. Human PBMCs were collected from normal donors and class-switched by the addition of IL-4 and anti-CD40. (a) Class-switched cells were added to ELISpot wells and spots were observed in the control well. The addition of MEDI4212 aFuc and the anti-migis antibody consistently reduced the number of spots to near zero. $* P<0.05$ for treatment group relative to media control (anti-CD40 and IL-4). One-way ANOVA followed by Dunnetts. (b) A substantial drop in the amount of IgE expression was observed by qPCR. IgE, immunoglobulin E; PBMC, peripheral blood mononuclear cell.

\section{DISCUSSION}

IgE is a critical player in allergic response and the phenotype associated with IgE in atopic individuals. The efficacy of omalizumab establishes the clinical benefit of IgE-neutralizing antibodies, but omalizumab does not treat the underlying disease etiology. Ongoing IgE B-cell differentiation and plasma cell secretion of IgE are likely to continue during and after omalizuamb treatment. Several groups have developed therapeutic antibodies that target only the membrane region of $\operatorname{IgE}$ expressed on the surface of memory B cells and mediate $\operatorname{IgE}$ B-cell killing. ${ }^{13-15}$ Quilizumab (an anti-IgE-M1 prime, membrane-specific $\mathrm{mAb}$ ) was shown to reduce total $\mathrm{IgE}$ and antigen-specific IgE in two recent clinical trials. ${ }^{40}$ In these studies, a modest reduction in total and antigen-specific IgE was observed, but it was not 'technically feasible' to identify or demonstrate the actual depletion of the very rare membrane IgE cells. ${ }^{40}$ Targeting membrane IgE alone should diminish the total amount of IgE being generated as the IgE secreting plasma cells die off and the new progenitor IgE B cells are eliminated by the anti-membrane IgE. There is limited evidence for both short-lived ${ }^{41,42}$ and longlived ${ }^{43} \mathrm{IgE}$ secreting plasma cells. Definitively establishing this is difficult due to the technical challenges associated with detecting the small portion of IgE plasma cells relative to the overwhelmingly large pool of IgG-secreting plasma cells. Studies by Lugar et al. $^{44}$ in mice suggest that after aerosol immunization, IgEsecreting plasma cells do not express membrane IgE, limiting the targeting capacity of a membrane-specific anti-IgE to memory B cells. Membrane-specific anti-IgE antibodies are not likely to replace omalizumab, but rather to be used as an add-onto, or in combination with, omalizumab.
We hypothesized that targeting primary IgE B cells would provide long-term benefit through the elimination of the IgE B-cell pool. Combining this mechanisms of action with omalizumab (soluble IgE neutralization) would provide both short- and long-term benefits. Enhancing ADCC activity of the MEDI4212 antibody should provide the increased longterm benefits associated with IgE B-cell elimination. In addition, higher affinity anti-IgE (MEDI4212) should provide clinical benefit to patients with a broader range of IgE expression levels and body weights.

Experimental systems available for testing the in vivo efficacy of ADCC-enhanced antibodies are limited. Within the oncology field, NOD $/ \mathrm{SCID} / \gamma \mathrm{c}^{\text {null }}$ mice have been used in conjunction with tumor cells, human NK cells and ADCC-enhanced anti-CD20 antibodies. ${ }^{45}$ These studies require a large number of K562 leukemia target cells $\left(1 \times 10^{7}\right.$ per mouse). Within the total human B-cell population, IgE-expressing B cells are exceptionally rare. Obtaining enough IgE-expressing primary target cells to facilitate in vivo studies is not feasible. In the absence of an in vivo system to target IgE-expressing B cells, we found that a limited number of isolated human B cells could be class-switched to IgE expressing cells and that these cells were susceptible to killing with an ADCC-enhanced antibody targeting IgE. What remains largely unknown is whether the ADCC-enhanced MEDI4212 would enhance IgE memory B-cell elimination in humans. IgG1 antibodies are known to stimulate modest levels of ADCC effector function, and since the number of target IgE B cells is very low and the antibody dose is likely to be high (omalizumab dose is $150-375 \mathrm{mg}$ ), it is possible that MEDI4212 WT (IgG1 without enhanced effector function) may facilitate ADCC mediated killing of the very rare and limited IgE B-cell population.

In follicular non-Hodgkin lymphoma patients treated with rituximab (anti-CD20, IgG1), 158V homozygous carriers had better outcomes than those carrying the $158 \mathrm{~F}$ genotype. ${ }^{37}$ This outcome is presumably due the FcyRIIIa polymorphic variant $158 \mathrm{~V}$, which has a much higher affinity for IgG1 $\mathrm{Fc}$ than 158F. Increasing the affinity of the antibody for of Fc $\gamma$ RIIIa provides a dramatic increase in bindingof $158 \mathrm{~F}$ compared to $158 \mathrm{~V}$. The increase in Fc $\gamma$ RIIIa affinity may broaden the efficacy of the antibody to include those patients that are homozygous $158 \mathrm{~F}$ carriers. However, as reported by others in small clinical trials, in our limited donor population we found only 3 V/V and 0 F/F out of 51 donors. ${ }^{37-39}$ In addition to NK cells, FcyRIIIa is also expressed on activated monocytes and macrophage subsets. ${ }^{46}$ Immune responses by monocyte- or macrophage-expressing F $\gamma$ RIIIa could also potentially be heightened upon of engagement of immune complexes containing enhanced FcyRIIIa affinity antibodies as has been shown with NK cells. The effects that these particular cell types have on the activity of the growing number of clinically validated Fc $\gamma$ RIIIa affinity-enhanced antibodies remain an open question.

Omalizumab is approved for use in atopic asthma, and has been effective as an add-on therapy. However, because of dosing restrictions dictated by the regulatory agencies, about 
one-third of severe asthmatics are not eligible for omalizumab due to high IgE levels and/or body weight. ${ }^{20}$ There are a number of reports that demonstrate an improvement in asthma in patients treated with omalizumab whose IgE levels exceeded the treatment guidelines. ${ }^{47,48}$ Modeling suggests that a highaffinity anti-IgE (MEDI4212) may expand the treatable population to include patients with higher IgE levels or body weights. ${ }^{20}$ ADCC-enhanced MEDI4212 has the potential to both neutralize soluble IgE and target IgE-expressing B cells through ADCC. This approach should have the combined benefits of soluble IgE neutralization and IgE B-cell elimination that, over time, should decrease the pool of IgE-secreting plasma cells.

\section{ACKNOWLEDGEMENTS}

The authors thank MedImmune LLC and MedImmune LTD (both solely owned by Astra Zeneca) for funding and resources to conduct the experiments contained herein. Additionally, we thank Robin Bolek for technical assistance with figure formatting. Lastly, we thank Nancy Craighead for editorial assistance with the manuscript and providing technical writing input.

1 Winter WE, Hardt NS, Fuhrman S. Immunoglobulin E: importance in parasitic infections and hypersensitivity responses. Arch Pathol Lab Med 2000; 124: 1382-1385.

2 Arbes SJ Jr, Gergen PJ, Vaughn B, Zeldin DC. Asthma cases attributable to atopy: results from the Third National Health and Nutrition Examination Survey. J Allergy Clin Immunol 2007; 120: 1139-1145.

3 Peters SP, Ferguson G, Deniz Y, Reisner C. Uncontrolled asthma: a review of the prevalence, disease burden and options for treatment. Respir Med 2006; 100: 1139-1151.

4 Wilcock LK, Francis JN, Durham SR. IgE-facilitated antigen presentation: role in allergy and the influence of allergen immunotherapy. Immunol Allergy Clin North Am 2006; 26: 333347, viii-ix.

5 Li H, Nowak-Wegrzyn A, Charlop-Powers Z, Shreffler W, Chehade M, Thomas $\mathrm{S}$ et al. Transcytosis of IgE-antigen complexes by CD23a in human intestinal epithelial cells and its role in food allergy. Gastroenterology 2006; 131: 47-58.

6 Palaniyandi S, Tomei E, Li Z, Conrad DH, Zhu X. CD23-dependent transcytosis of IgE and immune complex across the polarized human respiratory epithelial cells. J Immunol 2011; 186: 3484-3496.

7 Karagiannis SN, Bracher MG, Hunt J, McCloskey N, Beavil RL, Beavil AJ et al. IgE-antibody-dependent immunotherapy of solid tumors: cytotoxic and phagocytic mechanisms of eradication of ovarian cancer cells. J Immunol 2007; 179: 2832-2843.

8 Gould HJ, Sutton BJ, Beavil AJ, Beavil RL, McCloskey N, Coker HA et al. The biology of IGE and the basis of allergic disease. Annu Rev Immunol 2003; 21: 579-628.

9 Chang TW, Wu PC, Hsu CL, Hung AF. Anti-IgE antibodies for the treatment of IgE-mediated allergic diseases. Adv Immunol 2007; 93: 63-119.

10 MacGlashan DW Jr, Bochner BS, Adelman DC, Jardieu PM, Togias A, McKenzie-White $\mathrm{J}$ et al. Down-regulation of Fc\&RI expression on human basophils during in vivo treatment of atopic patients with anti-IgE antibody. J Immunol 1997; 158(3): 1438-1445.

11 Prussin C, Griffith DT, Boesel KM, Lin H, Foster B, Casale TB. Omalizumab treatment downregulates dendritic cell FcepsilonRI expression. J Allergy Clin Immunol 2003; 112: 1147-1154.

12 Chang TW, Shiung YY. Anti-lgE as a mast cell-stabilizing therapeutic agent. J Allergy Clin Immunol 2006; 117: 1203-1212; quiz 1213.
13 Chen JB, Wu PC, Hung AF, Chu CY, Tsai TF, Yu HM et al. Unique epitopes on $C$ epsilon $m X$ in IgE-B cell receptors are potentially applicable for targeting IgE-committed B cells. J Immunol 2010; 184: 1748-1756.

14 Chowdhury PS, Chen Y, Yang C, Cook KE, Nyborg AC, Ettinger R et al. Targeting the junction of C-epsilon- $\mathrm{mX}$ and epsilon-migis for the specific depletion of mlgE-expressing B cells. Mol Immunol 2012; 52: 279-288.

15 Feichtner S, Infuhr D, Achatz-Straussberger G, Schmid D, Karnowski A, Lamers $\mathrm{M}$ et al. Targeting the extracellular membrane-proximal domain of membrane-bound IgE by passive immunization blocks IgE synthesis in vivo. J Immunol 2008; 180: 5499-5505.

16 Firer MA. Might selective B-cell depletion have a place in targeted allergy therapy? J Hematol Res 2014; (1): 11-15

17 Desjarlais JR, Lazar GA. Modulation of antibody effector function. Exp Cell Res 2011; 317: 1278-1285.

18 Lazar GA, Dang W, Karki S, Vafa O, Peng JS, Hyun L et al. Engineered antibody FC variants with enhanced effector function. Proc Natl Acad Sci USA 2006; 103: 4005-4010.

19 Yamane-Ohnuki N, Kinoshita S, Inoue-Urakubo M, Kusunoki M, lida $\mathrm{S}$, Nakano R et al. Establishment of FUT8 knockout Chinese hamster ovary cells: an ideal host cell line for producing completely defucosylated antibodies with enhanced antibody-dependent cellular cytotoxicity. Biotechnol Bioeng 2004; 87: 614-622.

20 Cohen ES, Dobson CL, Kack H, Wang B, Sims DA, Lloyd CO et al. A novel IgE-neutralizing antibody for the treatment of severe uncontrolled asthma. MAbs 2014; 6: 756-764.

21 Persic L, Roberts A, Wilton J, Cattaneo A, Bradbury A, Hoogenboom HR. An integrated vector system for the eukaryotic expression of antibodies or their fragments after selection from phage display libraries. Gene 1997; 187: 9-18.

22 Oganesyan V, Damschroder MM, Leach W, Wu H, Dall'Acqua WF. Structural characterization of a mutated, ADCC-enhanced human Fc fragment. Mol Immunol 2008; 45: 1872-1882.

23 Ikeyama S, Nakagawa S, Arakawa M, Sugino H, Kakinuma A. Purification and characterization of IgE produced by human myeloma cell line, U266. Mol Immunol 1986; 23: 159-167.

24 Reth M. B cell antigen receptors. Curr Opin Immunol 1994; 6: 3-8.

25 Peng L, Oberst MD, Huang J, Brohawn P, Morehouse C, Lekstrom K et al. The CEA/CD3-bispecific antibody MEDI-565 (MT111) binds a nonlinear epitope in the full-length but not a short splice variant of CEA. PLoS One 2012; 7: e36412.

26 Kolbeck R, Kozhich A, Koike M, Peng L, Andersson CK, Damschroder MM et al. MEDI-563, a humanized anti-IL-5 receptor alpha mAb with enhanced antibody-dependent cell-mediated cytotoxicity function. $J$ Allergy Clin Immunol 2010; 125: 1344-1353.e2.

27 Litt MD, Simpson M, Gaszner M, Allis CD, Felsenfeld G. Correlation between histone lysine methylation and developmental changes at the chicken beta-globin locus. Science 2001; 293: 2453-2455.

28 Aramburu J, Azzoni L, Rao A, Perussia B. Activation and expression of the nuclear factors of activated T cells, NFATp and NFATc, in human natural killer cells: regulation upon CD16 ligand binding. J Exp Med 1995; 182: 801-810.

29 Koene HR, Kleijer M, Algra J, Roos D, von dem Borne AE, de Haas M. Fc gammaRIIla-158V/F polymorphism influences the binding of IgG by natural killer cell FC gammaRIlla, independently of the $\mathrm{F} C$ gammaRIIla-48L/R/H phenotype. Blood 1997; 90: 1109-1114.

30 Shields RL, Lai J, Keck R, O'Connell LY, Hong K, Meng YG et al. Lack of fucose on human IgG1 N-linked oligosaccharide improves binding to human Fcgamma RIII and antibody-dependent cellular toxicity. J Biol Chem 2002; 277: 26733-26740.

31 Shinkawa T, Nakamura K, Yamane N, Shoji-Hosaka E, Kanda Y, Sakurada $\mathrm{M}$ et al. The absence of fucose but not the presence of galactose or bisecting $\mathrm{N}$-acetylglucosamine of human IgG1 complextype oligosaccharides shows the critical role of enhancing antibodydependent cellular cytotoxicity. J Biol Chem 2003; 278: 3466-3473.

32 Awan FT, Lapalombella R, Trotta R, Butchar JP, Yu B, Benson DM Jr et al. CD19 targeting of chronic lymphocytic leukemia with a novel Fc-domain-engineered monoclonal antibody. Blood 2010; 115: 1204-1213. 
33 Gascan H, Gauchat JF, Aversa G, Van Vlasselaer P, de Vries JE. AntiCD40 monoclonal antibodies or $\mathrm{CD}^{+}{ }^{+} \mathrm{T}$ cell clones and IL-4 induce IgG4 and IgE switching in purified human B cells via different signaling pathways. J Immunol 1991; 147: 8-13.

34 Milovanovic M, Drozdenko G, Weise C, Babina M, Worm M. Interleukin-17A promotes IgE production in human B cells. J Invest Dermatol 2010; 130: 2621-2628.

35 Avery DT, Ma CS, Bryant VL, Santner-Nanan B, Nanan R, Wong M et al. STAT3 is required for IL-21-induced secretion of IgE from human naive B cells. Blood 2008; 112:1784-1793.

36 Kobayashi S, Haruo N, Sugane K, Ochs HD, Agematsu K. Interleukin21 stimulates $B$-cell immunoglobulin $E$ synthesis in human beings concomitantly with activation-induced cytidine deaminase expression and differentiation into plasma cells. Hum Immunol 2009; 70: 35-40.

37 Cartron G, Dacheux L, Salles G, Solal-Celigny P, Bardos P, Colombat P et al. Therapeutic activity of humanized anti-CD20 monoclonal antibody and polymorphism in IgG Fc receptor FcgammaRIIla gene. Blood 2002; 99: 754-758.

38 Weng WK, Levy R. Two immunoglobulin G fragment C receptor polymorphisms independently predict response to rituximab in patients with follicular lymphoma. J Clin Oncol 2003; 21: 3940 3947.

39 Matlawska-Wasowska K, Ward E, Stevens S, Wang Y, Herbst R, Winter SS et al. Macrophage and NK-mediated killing of precursor-B acute lymphoblastic leukemia cells targeted with a-fucosylated anti-CD19 humanized antibodies. Leukemia 2013; 27: 1263-1274.

40 Gauvreau GM, Harris JM, Boulet LP, Scheerens H, Fitzgerald JM, Putnam WS et al. Targeting membrane-expressed IgE B cell receptor with an antibody to the $\mathrm{M} 1$ prime epitope reduces IgE production. Sci Transl Med 2014; 6: 243 ra85.

41 Johansson SG, Bennich H, Berg T, Hogman C. Some factors influencing the serum IgE levels in atopic diseases. Clin Exp Immunol 1970; 6: 43-47.
42 Yunginger JW, Gleich GJ. Seasonal changes in IgE antibodies and their relationship to IgG antibodies during immunotherapy for ragweed hay fever. J Clin Invest 1973; 52: 1268-1275.

43 Hallstrand TS, Sprenger JD, Agosti JM, Longton GM, Witherspoon RP, Henderson WR Jr. Long-term acquisition of allergen-specific IgE and asthma following allogeneic bone marrow transplantation from allergic donors. Blood 2004; 104: 3086-3090.

44 Luger EO, Fokuhl V, Wegmann M, Abram M, Tillack K, Achatz G et al. Induction of long-lived allergen-specific plasma cells by mucosal allergen challenge. J Allergy Clin Immunol 2009; 124: 819-826.e4.

45 Shiokawa M, Takahashi T, Murakami A, Kita S, Ito M, Sugamura K et al. In vivo assay of human NK-dependent ADCC using NOD/SCID/ gammac $_{\text {null }}$ (NOG) mice. Biochem Biophys Res Commun 2010; 399: 733-737.

46 Ziegler-Heitbrock HW. Heterogeneity of human blood monocytes: the $\mathrm{CD} 14^{+} \mathrm{CD}_{16}{ }^{+}$subpopulation. Immunol Today 1996; 17: 424428.

47 Lin RY, Sethi S, Bhargave GA. Measured immunoglobulin E in allergic bronchopulmonary aspergillosis treated with omalizumab. J Asthma 2010; 47: 942-945.

48 Maselli DJ, Singh H, Diaz J, Peters JI. Efficacy of omalizumab in asthmatic patients with IgE levels above $700 \mathrm{IU} / \mathrm{mL}$ : a retrospective study. Ann Allergy Asthma Immunol 2013; 110: 457-461.

cc) (i) (\$) $\odot$ This work is licensed under a Creative Commons Attribution-NonCommercial-NoDerivs 3.0 Unported

License. The images or other third party material in this article are included in the article's Creative Commons license, unless indicated otherwise in the credit line; if the material is not included under the Creative Commons license, users will need to obtain permission from the license holder to reproduce the material. To view a copy of this license, visit http://creativecommons.org/licenses/by-nc-nd/3.0/ 